\title{
Effects of Soft X-Ray Irradiation on Ocular Development in Sprague-Dawley Rats
}

\author{
Hiroshi KUNO, Masayuki KEMI, Michiyo AKIMOTO, Takaaki FUJII, \\ and Toshimi USUI
}

Banyu Pharmaceutical Co., Ltd., Development Research Laboratories, 810 Nishijo, Menuma-machi, Ohsato-gun, Saitama 360-02, Japan

(Received 26 February 1993/Accepted 30 March 1993)

\begin{abstract}
Pregnant rats were irradiated with soft $\mathrm{x}$-rays at a dose of $1.6,3.2,6.3$ or $12.6 \mathrm{~Gy}$ on Day 9 of gestation, and the eyes of $F_{1}$ offspring were examined using indirect ophthalmoscopy and biomicroscopy during Postnatal Week 5. Ophthalmoscopic examination revealed iris and choroidal coloboma, microphthalmia and anophthalmia in the 3.2, 6.3 and 12.6 Gy groups. In addition to those anomalies, lens luxation and associated anterior displacement of the vitreous face, and retinal vascular anomalies were observed in the $12.6 \mathrm{~Gy}$ group. Histological examination revealed agenesis of retinal vessels. Ophthalmoscopic examination using biomicroscopy and indirect ophthalmoscopy detected choroidal coloboma, lens and vitreous luxation and defect in retinal vessels which could not be detected by external observation, demonstrating the usefulness of this technique in the postnatal stage of teratology studies. - KEY WORDS : ophthalmoscopy, rats, soft $\mathrm{x}$-ray, teratology
\end{abstract}

Ocular teratogenic effects of ochratoxin A $[14,15]$, vincristine [20], cyclophosphamide $[1,10,16,17]$ and $x$-ray irradiation $[9,11,13$, $18,19]$ can be observed by histologic examination of fetal serial sections in rats and mice. However, in routine teratology studies for detecting a potential hazardous effect of test compounds on developing eyes, time-consuming histologic examination of serial sections of fetuses is impractical because of the large number of fetuses examined. The present study was performed to determine the usefulness of ophthalmoscopic examination as one of the postnatal observations in teratology studies using soft $\mathrm{x}$-ray as the model teratogen.

\section{Materials and Methods}

1. Animals : Albino Sprague-Dawley rats of the Crj:CD (SD) strain were purchased from Charles River Japan (Hino, Shiga) and maintained in an animal room with a regulated temperature of $22 \pm 2^{\circ} \mathrm{C}$, a relative humidity of $55 \pm 10 \%$ and a 12 hour light/dark cycle. All animals had free access to pelleted rodent chow, CRF-1 (Oriental Yeast Inc.), and tap water. Virgin females of 12 weeks of age were paired with adult males of the same strain overnight. The day on which a copulation plug was found was designated as Day 0 of gestation.

2. Soft $x$-ray irradiation : On Day 9 of gestation, 6 to 10 pregnant rats in each group were anesthetized with $50 \mathrm{mg} / \mathrm{kg}$ of sodium pentobarbital given intraperitoneally, and the whole body was soft $x$-ray irradiated once at a dose of $1.6,3.2,6.3$ or $12.6 \mathrm{~Gy}$ (Table 1). Irradiation was performed with a soft $\mathrm{x}$-ray apparatus (CMB-W, Softex Co., Ltd), with radiation factors of $4.03 \mathrm{~A}, 50 \mathrm{kVp}, 2.5 \mathrm{~mA}$, a target distance of $60 \mathrm{~cm}$ and an exposure rate of $0.63 \mathrm{~Gy}$ per minute. Takeuchi and Takeuchi [19] reported a high frequency of micro-or anophthalmia in rat offspring whose mothers were $x$-ray irradiated on Day 9 of gestation. In addition, our preliminary study demonstrated that soft $\mathrm{x}$-ray irradiation on Day 9 of gestation produced ophthalmic abnormalities in rat $F_{1}$ offspring [6]. We, therefore, selected Day 9 of gestation for soft $x$-ray irradiation in this study. Since soft $\mathrm{x}$-ray irradiation at a dose of 12.6 Gy on Day 9 of gestation produced ocular 
Table 1. Postnatal mortality of rat $F_{1}$ offspring soft X-ray irradiated on Day 9 of gestation

\begin{tabular}{lccccc}
\hline \multicolumn{1}{c}{ Groups } & Control & $1.6 \mathrm{~Gy}$ & $3.2 \mathrm{~Gy}$ & $6.3 \mathrm{~Gy}$ & $12.6 \mathrm{~Gy}$ \\
\hline No. pregnant rats & 8 & 7 & 7 & 6 & 10 \\
No. offspring delivered & 112 & 111 & 108 & 91 & 103 \\
Deaths in total (\%) & 5.4 & 1.8 & 4.6 & 5.5 & 18.4 \\
Deaths during lactation (\%) & & & & & \\
$\quad$ Postnatal days 0-3 & 4.5 & 0.9 & 1.8 & $2.2^{\mathrm{NS}}$ & $12.6^{\mathrm{s}}$ \\
$\quad$ Postnatal days 4-21 & 0.9 & 0.9 & 2.8 & 2.2 & $1^{\mathrm{NS}}$ \\
Deaths after weaning (\%) & 0 & 0 & 0 & 0 & $4.9^{\mathrm{NS}}$ \\
\hline
\end{tabular}

$\mathrm{S}$ : Statistically significant $(\mathrm{P} \leq 0.05)$ from the control (trend test) NS : Not statistically significant $(\mathrm{P}>0.05)$ from the control (trend test)

Table 2. Ophthalmic abnormalities the anterior segment of eyes found during postnatal Week 5 in rat $F_{1}$ offspring prenatally soft $\mathrm{X}$-ray irradiated

\begin{tabular}{lcccccc}
\hline \multicolumn{1}{c}{ Groups } & Control & $1.6 \mathrm{~Gy}$ & $3.2 \mathrm{~Gy}$ & $6.3 \mathrm{~Gy}$ & $12.6 \mathrm{~Gy}$ & $\begin{array}{c}\text { Background } \\
\text { Control Data }\end{array}$ \\
\hline No. offspring examined & 107 & 109 & 103 & 86 & 83 & 1170 \\
Anophthalmia (\%) & 0.0 & 0.0 & $1.0^{\mathrm{NS}}$ & $5.8^{\mathrm{s}}$ & $10.8^{\mathrm{S}}$ & 0 \\
Microphthalmia (\%) & 0.0 & 0.0 & 1.0 & $1.2^{\mathrm{NS}}$ & $24.1^{\mathrm{s}}$ & 0 \\
Iris coloboma (\%) & 0.0 & 0.0 & 1.0 & $1.2^{\mathrm{Ns}}$ & $20.5^{\mathrm{s}}$ & 0 \\
Vitreous Displacement (\%) & 0.0 & 0.0 & 0.0 & 0.0 & $1.2^{\mathrm{Ns}}$ & 0 \\
Lens luxation (\%) & 0.0 & 0.0 & 0.0 & 0.0 & $1.2^{\mathrm{Ns}}$ & 0.1 \\
\hline
\end{tabular}

The ocular anterior segment was examined with a biomicroscope during postnatal week 5. $\%$ : Animals with ocular lesions / animals examined $\times 100 \quad \mathrm{~S}$ : Statistically significant $(\mathrm{P} \leq 0.05)$ from the control (trend test) NS: Not statistically significant $(\mathrm{P}>0.05)$ from the control (trend test)

abnormalities in rat $F_{1}$ offspring, $12.6 \mathrm{~Gy}$ was used as the highest dose in this study, and the lower doses were set at $6.4,3.2$ and $1.6 \mathrm{~Gy}$. In addition, 8 pregnant rats were anesthetized with sodium pentobarbital in the same way as in the irradiation groups and served as controls.

3. Examination: On the day of whelping, designated as Postnatal Day 0 , the number of neonates was recorded. The newborns were examined for survival and external abnormalities throughout the study period.

During Postnatal Week 5, the eyes of the $F_{1}$ offspring were examined by one person using a biomicroscope and an indirect ophthalmoscope in a dimly lit animal room.

One $F_{1}$ animal with abnormalities of retinal vessels in the $12.6 \mathrm{~Gy}$ group was anesthesized with pentobarbital sodium at a dose of 50 $\mathrm{mg} / \mathrm{kg}$ ip. The eyes were removed after perfusion-fixation with $2 \%$ formaldehyde and $1.5 \%$ glutalaldehyde, and histological sections stained with Hematoxylin and Eosin were examined.
4. Statistical evaluation: Statistical analysis of postnatal mortality and ophthalmologic lesions were conducted on affected pups on a per litter basis. The No-Statistical-Significance-Of-Trend (NOSTASOT) trend test [21] evaluated by exact Conditional Randomization Test [8] was used to assess the dose effect for each parameter. The NOSTASOT trend test (1-sided) of dose effect was significant if $\mathrm{P} \leqq$ 0.05 and not significant if $\mathrm{P}>0.05$.

\section{Results}

1. Mortality : There was a statistically significant $(\mathrm{P} \leqq 0.05)$ increase in mortality for postnatal days 0 to 3 in the 12.6 Gy group (Table 1). There were no treatment-related changes in mortality after postnatal day 4 (Table 1).

2. External abnormalities : Macroscopic examination revealed bilateral clubbed foot in 1 $F_{1}$ animal from the $3.2 \mathrm{~Gy}$ group and rudimentary tail in $1 \mathrm{~F}_{1}$ animal from each of the 6.3 and $12.6 \mathrm{~Gy}$ groups. Hydrocephalus, a misshapen 
Table 3. Ophthalmic abnormalities in the ocular fundus found during postnatal

Week 5 in rat $F_{1}$ offspring prenatally soft $\mathrm{X}$-ray irradiated

\begin{tabular}{lrrrrrr}
\hline \multicolumn{1}{c}{ Groups } & Control & $1.6 \mathrm{~Gy}$ & $3.2 \mathrm{~Gy}$ & $6.3 \mathrm{~Gy}$ & $12.6 \mathrm{~Gy}$ & $\begin{array}{c}\text { Background } \\
\text { control Data }\end{array}$ \\
\hline No. offspring examined & 107 & 109 & 103 & 83 & 78 & 1170 \\
Defect of retinal vessels (\%) & 0.0 & 0.0 & 0.0 & 0.0 & $2.6^{\mathrm{NS}}$ & 0.0 \\
Choroidal coloboma (\%) & 0.0 & 0.0 & 1.9 & $1.2^{\mathrm{NS}}$ & $28.2^{\mathrm{s}}$ & 0.2 \\
\hline
\end{tabular}

The ocular fundus was examined with an indirect ophthalmoscope during postnatal week $5 . \quad \%$ : Animals with ocular lesions / animals examined $\times 100 \quad \mathrm{~S}$ : Statistically significant $(\mathrm{P} \leq 0.05)$ from the control (trend test) NS : Not statistically significant $(\mathrm{P}>0.05)$ from the control (trend test)

ear and malocclusion were observed in 4,1 and $1 \mathrm{~F}_{1}$ animals, respectively, from the $12.6 \mathrm{~Gy}$ group.

3. Ocular abnormalities : Anophthalmia was unilaterally or bilaterally observed in 1.0 $\%, 5.8 \%$ and $10.8 \%$ of the offspring in the 3.2 , 6.3 and $12.6 \mathrm{~Gy}$ groups, respectively (Table 2 ) . Histologic examination of several eyes with anophthalmia diagnosed clinically revealed remnants of a dysplastic, microphthalmic globe in the deep orbital cavity. Unilateral or bilateral microphthalmia was seen in $1.0 \%$, $1.2 \%$ and $24.1 \%$ of the offspring in the 3.2 , 6.3 and 12.6 Gy group, respectively (Table 2 ). The incidences of anophthalmia and microphthalmia were statistically significant $(P \leqq 0.05)$ in the 6.3 and/or $12.6 \mathrm{~Gy}$ groups. A micropalpebral fissure was present in the eyes with anophthalmia and microphthalmia (Fig. 1) .

A unilateral or bilateral coloboma of the iris, localized in the inferonasal quadrant, was present in $1.0 \%, 1.2 \%$ and $20.5 \%$ of the offspring in the $3.2,6.3$ and $12.6 \mathrm{~Gy}$ group, respectively (Table 2). Iris colobomas were typically associated with microphthalmia. The incidence of iris coloboma in the $12.6 \mathrm{~Gy}$ group was statistically significant $(\mathrm{P} \leqq 0.05)$. Macroscopic examination of enucleated eyes with iris coloboma revealed a defect in the iris, ciliary body and retina along the optic fissure, suggesting abnormal closure of the fissure. The distance between the base of the iris and optic nerve along the optic fissure was approximately two thirds of the normal distance.

In addition to those abnormalities in the anterior segment, lens luxation and vitreous displacement into the anterior chamber were unilaterally observed in $1.2 \%$ of the offspring in the 12.6 Gy group.
Unilateral or bilateral choroidal coloboma associated with optic nerve coloboma was ophthalmoscopically characterized by a focal well-demarcated, less vascularized, oval pale area adjacent to the optic nerve in the inferonasal quadrant (Fig. 2). The optic disc was oval and appeared 2 times larger than normal. The central retinal artery and vein were shifted to the periphery of the optic disc. Choroidal coloboma was seen in $1.9 \%, 1.2 \%$ and $28.2 \%$ of the offspring in the $3.2,6.3$ and $12.6 \mathrm{~Gy}$ group, respectively (Table 3 ). There was a statistically significant $(\mathrm{P} \leqq 0.05)$ increase in the incidence of this lesion in the $12.6 \mathrm{~Gy}$ group.

A defect in the retinal vessels was unilaterally observed in 2 rats and was associated with microphthalmia (Table 3 ). In these eyes persistence of the anterior hyaloid vessels was observed (Fig. 3). There were no detectable abnormalities in the choroidal vessels by indirect ophthalmoscopy. Histomorphological examination of one abnormal eye with clinically abnormal retinal vasculature revealed vessels behind the posterior lens capsule (Fig. 4) and hypoplasia of the neural retina with degeneration of the photoreceptor (Fig. 5) .

In addition to the irradiation-related lesions, there were also ophthalmoscopic lesions such as corneal crystal, iritis, persistent pupillary membrane, incipient cataract, vitreous hemorrhage, retinal hemorrhage, focal choroidal defect and retinal fold. These ophthalmoscopic lesions are commonly observed in SD rats in our laboratories and are considered incidental. The prevalence of these lesions did not differ between the control and treated groups. 


\section{Discussion}

Pregnant rats were subjected to whole body soft $x$-ray irradiation once at a dose of $1.6,3.2,6.3$ or $12.6 \mathrm{~Gy}$ on Day 9 of gestation. Major ocular anomalies induced by soft $\mathrm{x}$-ray irradiation were observed at 6.3 and $12.6 \mathrm{~Gy}$ in rat $F_{1}$ offspring and were iris and choroidal coloboma, microphthalmia and anophthalmia. These ocular anomalies were also observed in the $3.2 \mathrm{~Gy}$ group. The incidence of the changes in this group was not statistically significant, but these ocular abnormalities are not common in our historical control data and are considered to be related to soft $x$-ray irradiation.

In addition, lens luxation and vitreous displacement into the anterior chamber, and retinal vessel attenuation were observed at 12.6 $\mathrm{Gy}$. These changes are extremely rare or non -existent in our historical control data and considered to be related to soft $\mathrm{x}$-ray irradiation, suggesting that accumulation of historical control data of spontaneous ocular lesions for each breed and strain is essential for evaluation of potential ocular toxicity.

Cook reported that microphthalmia may occur early in development through malformation of the optic vesicle, or later through failure of normal growth and enlargement of the globe [4]. Iris and choroidal coloboma were seen in the inferonasal portion of the eye and are categorized as a "typical" coloboma. Typical coloboma is induced through failure of the choroidal fissure to close [22].

Coulombre reported that the reduction of intraocular pressure (IOP) markedly slows enlargement of the eye [5]. In our study, a defect in the ciliary body was macroscopically observed along the optic fissure, suggesting that decreased IOP in the developing eye may contribute to microphthalmia .

Cook has reported that microphthalmia produces a cascade of malformations in the developing eye : remnant of primary vitreous, cataract, and anterior segment dysgenesis [4]. Lens luxation associated with vitreous displace. ment into the anterior chamber, persistence of the primary vitreous and agenesis of the retinal vessels observed in this study might be secondary to microphthalmia .

Hypoplasia of the neural retina was observed in the eye with agenesis of the retinal vessels. Retinal nutrition is derived from the retinal and choroidal capillaries, and possibly from the vitreous [12]. Leeson reported that retinal arterioles are present in the nerve fiber layer, and capillaries are present in the retina and form plexuses in the nerve fiber ganglion cell layer, between the inner plexiform and inner nuclear layers and between the inner nuclear and outer plexiform layers [7]. The study of morphogenesis of the retina in Sprague -Dawley rats demonstrates formation of a single neuroblastic layer in the neural retina on gestational day 11 with maturation of the neural retina by postnatal day 14 [2]. In addition, capillaries in the nerve fiber ganglion cell layer are seen on postnatal day 4 [2]. Since all layers of the neural retina were present, although hypoplastic, in the eyes with agenesis of the retinal vessels, the change might be related to secondary nutritional problems due to agenesis of the retinal vessels.

Choroidal coloboma, lens and vitreous luxation and defects in retinal vessels, which could not be detected by external observation, were detected by ophthalmoscopic examination with a biomicroscope and indirect ophthalmoscope, demonstrating the usefulness of this technique in the postnatal stage of teratology studies.

The authors wish to thank Dr. David A. Wilkie (Department of Veterinary Clinical Sciences, College of Veterinary Medicine, The Ohio State University) for valuable advice in preparing the manuscript and Ms. C. M. Hoe (Biometrics Research, Merck Research Laboratories) for statistical analysis.

\section{References}

[1] Borzyskowski M., Harris R. F., and Jones R.W.A. (1981). The congenital varicella syndrome. Eur $J$ Pediatr., 137, 335-338.

[2] Braekevelt R. C. and Hollenberg J. M. (1970). The development of the retina of the albino rat. $A m J$ Anat., 127, 281-302.

[3] Chamberlain J. G. and Nelson M. M. (1963) . Congenital abnormalities in the rat resulting from single injections of a 6-aminonicotinamide during pregnancy. $J$ Exp Zool., 153, 285-295.

[4] Cook S. C. (1992). Embryogenesis of ocular malformations. In Proceedings of 43rd annual meeting of the American College of Veterinary Pathologists., pp 88 -105, San Diego.

[5] Coulombre A. J. (1956). The role of intraocular pres sure in the development of the chick eye. J Exp Zool., 133, 211-225.

[6] Kuno H., Inagaki S., Ban Y., Konishi R., Tanaka K., Fujii T ., and Usui T. (1992). Usefulness of ophthalmic examination in postnatal examination in post. 
natal observation in teratology studies. Exp Anim., 41, 363-367.

[ 7 ] Leeson S. T. (1979). Rat retinal blood vessels. Canad $J$ Ophthal., 14, 21-28.

[ 8 ] Mehta C. and Patel N. (1991). R x C Tables. In StatXact 2ed., pp 54-65, Cytel Corporation, Cambridge, MA

[9] Murakami U. (1968). Effects of x-irradiation with relation to abnormal morphogenesis. Cong Anom ., 8, 147-162.

[10] Peiffer L. R., McCullen R., Alles J. A., and Sulik K. K. (1991) . Relationship of cell death to cyclophosphamide-induced ocular malformations. Ter atogenesis, Carcinogenesis, and Mutagenesis., 11, 203 -212 .

[11] Sakurai T. (1968). Effects of $x$-irradiation upon the developing eye and the mechanism forming malformations of the eye. Cong Anom., 8, 1-11.

[12] Samuelson A. D. (1991). Ophthalmic embryology and anatomy: Retina. In Veterinary ophthalmology 2nd ed., pp92, Gelatt N. K. (ed), Lea \& Febiger, Philadelphia.

[13] Shirai S. (1978). Eye abnormalities in mouse fetuses caused by simultaneous irradiation of $\mathrm{x}$-rays and ultrasound: II. Developmental abnormalities of the eye. Cong Anom., 18, 269-279.

[14] Shirai S., Ohshika S., Yuguchi S., and Majima A. (1984). Ochratoxin A: I. Developmental eye anomalies in mouse fetuses induced by ochratoxin A. Acta Soc Ophthalmol Jpn., 88, 627-634.
[15] Shirai S., Ohshika S., Yuguchi S., and Majima A. (1985). Ochratoxin A: III. Developmental abnormalities of the anterior segment of the eye induced in mice by ochratoxin A. Acta Soc Ophthalmol Jpn., 89, 753 -760 .

[16] Singh S. and Sanyal A. K. (1976). Eye anomalies induced by cyclophosphamide in rat fetuses. Acta Anat., 94, 490-500.

[17] Singh S., Jeyaseelan N., Singh S., and Mehra S. K. (1984). Histological study of eye malformation induced by cyclophosphamide in rat foetuses. Indian $J$ Med Res., 79, 684-690.

[18] Takeuchi K. I. and Takeuchi K. Y. (1986) . Congenital hydrocephalus following $\mathrm{x}$-irradiation of pregnant rats on an early gestational day. Neurobehavioral Toxicology and Teratology, 8, 143-150.

[19] Takeuchi K. Y., Kitoh J., Sakai H., and Takeuchi K. I. (1988) . Aplasia of the optic nerve in microphthalmic offspring of prenatally $\mathrm{x}$-irradiated rats. Cong Anom. , 28, 179-186.

[20] Tamaki M. (1969). Malformation of the eye in rat fetuses caused by vincristine and their abnormal morphogenesis. Cong Anom., 9, 157-70.

[21] Turkey J.W ., Ciminera J.L., and Heyse J.F. (1985) . Testing the statistical certainly of a response to increasing doses of a drug. Biometrics, 41, $295-301$.

[22] Yanoff M. and Fine S. B. (1989). Coloboma. In Ocular pathology: a text and atlas, 3rd ed., pp 322 -324 , Yanoff M. and Fine S. B., J.B. Lippincott Company, Philadelphia.

\title{
ラットにおける軟X線の眼の発生に及ぼす影響
}

\author{
久野博司・花見正幸・秋元倫代 \\ 藤井孝朗・白居敏仁
}

萬有製薬株式会社開発研究所

妊娠 9 日のCRJ : CDラットに軟X線を 1.6, 3.2, 6.3 または $12.6 \mathrm{~Gy}$ の線量で照射し, 生後 3 または 5 週秢の $F_{1}$ 産児の眼科学的な異常を倒像検眼鏡および 細隙燈顕微鏡を用いて検査した。3.2, 6.3 または 12.6 Gyの線量で照射した $\mathrm{F}_{1}$ 産児の観察において, 小眼球 症, 無眼球症, 虹彩のコロボーマおよび脈絡膜のコロ ボーマが観察された。12.6 Gyの線量では, さらに水晶
体脱臼，硝子体脱臼および網膜血管の欠損が認められ た。網膜血管の欠損は, 組織学的に網膜血管の無形成 と診断された。外形観察で観察することができない水 晶体および硝子体の脱臼, 網膜血管の欠損および脈絡 膜のコロボーマが細隚燈顕微鏡あるいは倒像顕微鏡 により観察されたことは, 生殖毒性試験の生後観察と してこれら眼科学的検査の有用性が強く示咬された。 


\section{Explanation of Figures}

Fig. 1. Micropalpebral fissure observed in a microphthalmic eye. The left rat has a normal eye ball and a right rat has a small eye ball.

Fig. 2. Choroidal coloboma and nerve coloboma. Choroidal coloboma was characterized by a fairly well demarcated, less vascularized, pale area adjacent to the optic nerve in the inferonasal quadrant. Nerve coloboma was oval and approximately 2 times larger than normal.

Fig. 3. Persistence of the anterior hyaloid vessels. The

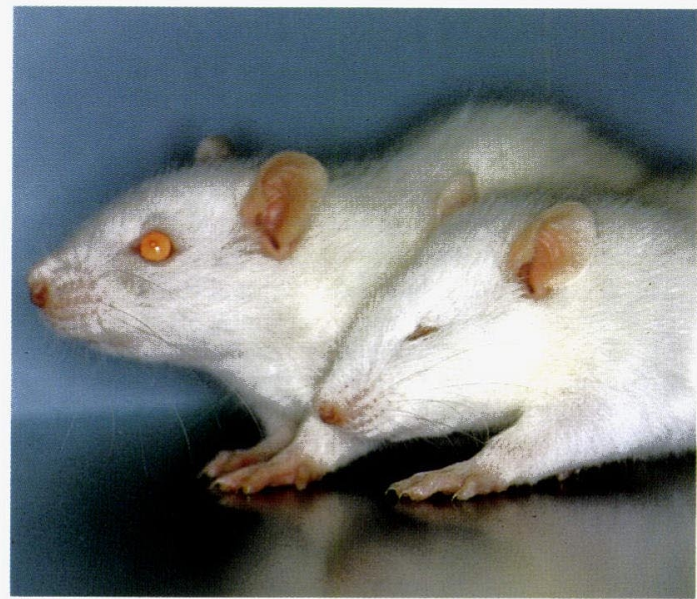

Fig. 1.

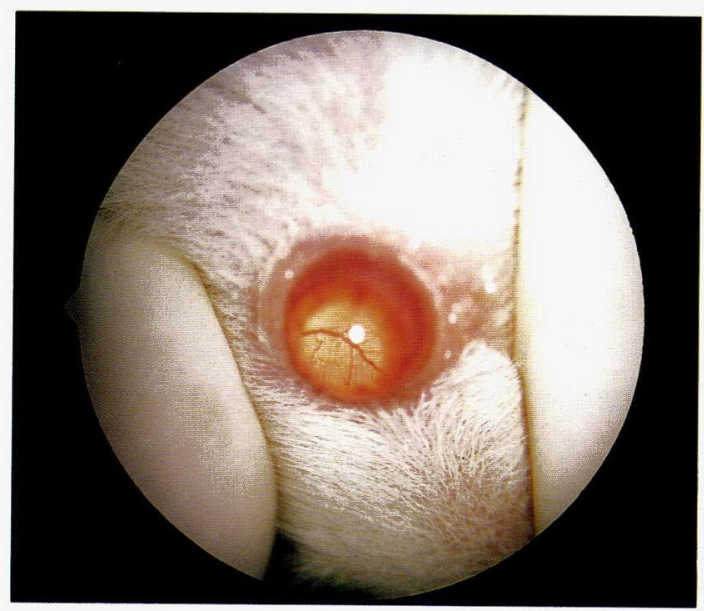

Fig. 3. vessels were localized just behind the posterior lens capsule.

Fig. 4. Histological appearance of the persistence of the anterior hyaloid vessels.

Fig. 5. A ; Normal retina. B ; Hypoplasia of the neural retina. All layers of the neural retina were present, but were hypoplastic. Retinal arterioles and capillaries were not present.

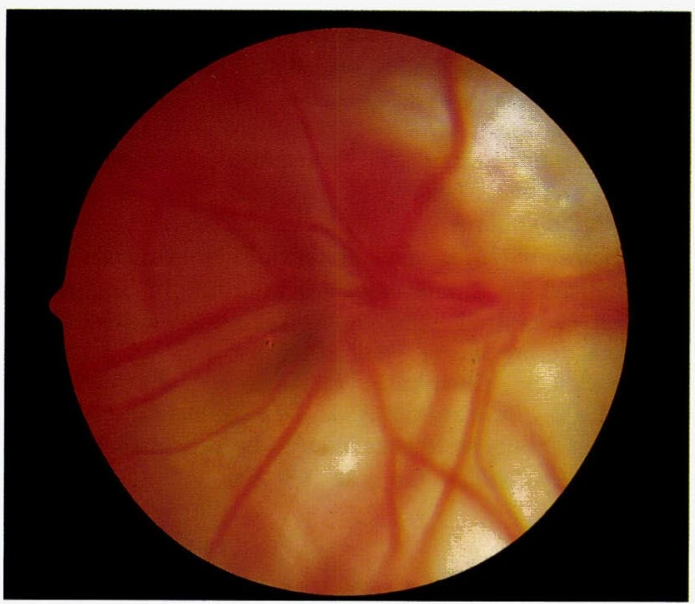

Fig. 2 .
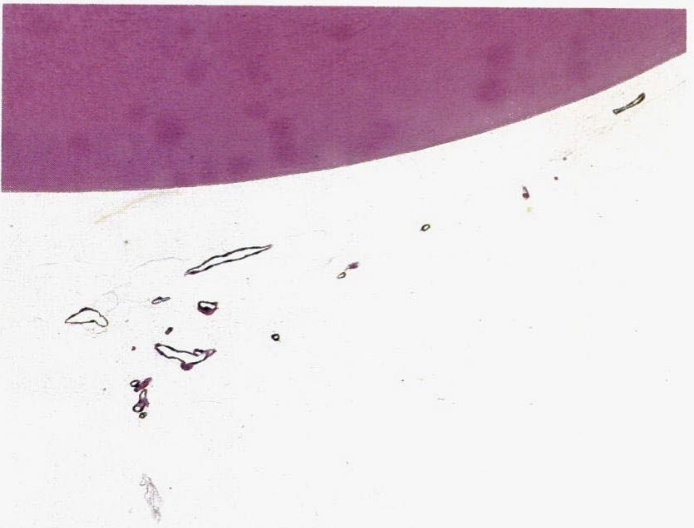

Fig. 4 . 


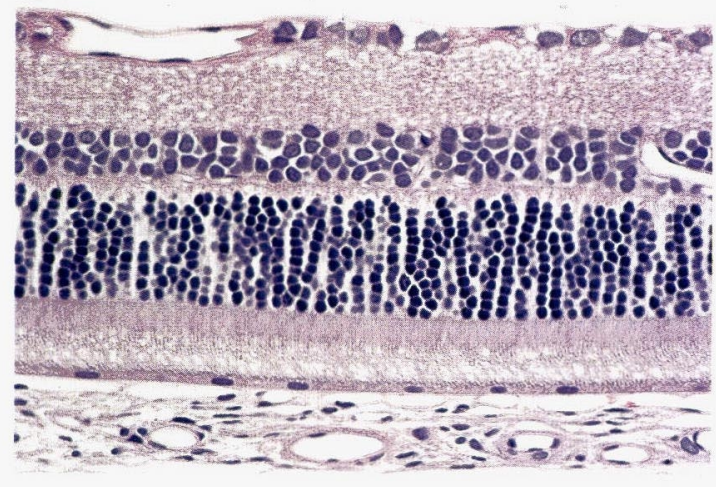

Fig. 5A.

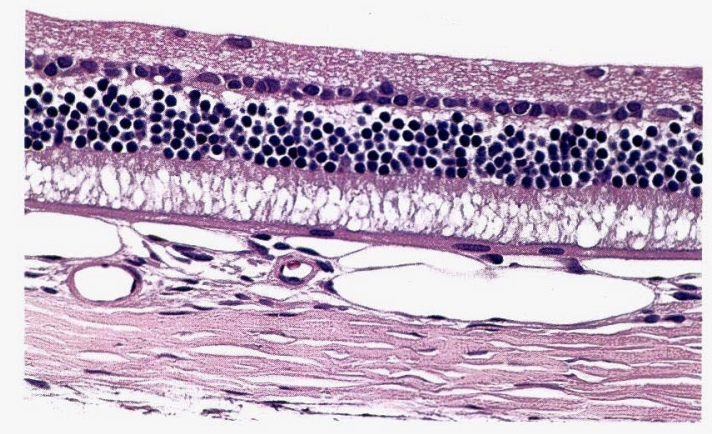

Fig. 5B. 